\title{
Sense of Belonging in Jhumpa Lahiri'The Namesake
}

\author{
Asst Prof. Ms Yogita Sahni \\ Department of English Arya Girls P.G College, Shahabad (M)
}

\begin{abstract}
With increasing economic development and faster modes of communication, the individual in society faces a number of problems, about his place in the scheme of things. Increasing urbanization leads to a loss of self-identity because the old traditions have lost their values and an individual starts feeling alienated from the past which frequently results in a loss of sense of belonging or crisis of identity for many people. The concept of alienation has played an important part in the history of philosophical and sociological thought of the past. Alienation is the feeling that life is meaningless and we do not belong in this world. There are three types of alienation, alienation from oneself, alienation from other people and alienation from the world in which one lives and these three forms of alienation are interrelated. It is the process whereby people become foreigner to the world they are living in. Modern man does not feel sense of belonging to any person or society or country because he wants to live in isolation and influence of money power. He thinks that he can live alone in the world without being attached to any person. Sometimes he decides to search about his self-identity. He wants to remain detached but comes to realize at the end that there is no escape from life and its sufferings. If a person wants to live happily he will have to involve himself with other human beings. He will have to perform his actions without any desires. When he realizes this fact then he feels sense of belonging and true meaning of life. When a man leaves his country and goes to another country for better opportunities then he feels himself a stranger there. He wants to connect himself to that place but his past relations and customs always overpowers him there. But after spending many years in another country when he comes back to his own country then he feels belonging to the people and country.
\end{abstract}

Key Words: Alienation, Belongings, Identity-Crisis, Immigrant, Nostalgic

Jhumpa Lahiri's novel The Namesake reflects the problem of search for identity and sense of belonging. The aimless wandering, search for identity and alienation is a common-place theme in modern fiction, but for the most Indian novelists in English this quest has peculiar Indian immediacy. Moving between events in Calcutta, Boston and New York city, the novel examines the nuances involved with being caught between two conflicting cultures with their highly distinct religious, social ideological differences. Michiko Kakutani says:

The Namesake is a novel that offers a Chekhovian exploration of father and sons,

Parents and children, as it is resonant in its exploration of what is acquired and lost

by immigrants and their children in pursuit of American Dream.1

JhumpaLahiri's treatment of alienation, her persistent delineation of rootless characters and an awareness of her unfortunate predicament are symptomatic of her own problems. Lahiri seems at home with the expatriate community of Bengali in the Boston area, their peculiarly lonely lives with extended families made up of fellow expatriates, the custom and world view through which they see their own everyday experiences, and the struggle of their American children with their own questions of identity and belonging. The experience of exile is Lahiri's personal experience. In a way The Namesake is a personal experience, which is made a communal occurrence. Growing up with ties to all three countries created in her a sense of homelessness and an inability to feel accepted. Lahiri explains this inheritance of her parents' ties to India:

It's hard to have parents who consider another place 'home'-even after living abroad for thirty years, India is home for them. We were always looking back so I never felt fully at home here. There is nobody in this whole country that we are related to ....we were clutching at a world that was never fully with us.2

In The Namesake Lahiri enriches the themes that made her collection an international best seller: the immigrant experience, the clash of cultures, the conflicts of assimilation, and most poignantly, the tangled ties between generations. Here again she displays her deft touch for the perfect detail-the fleeting moment, the turn of phrasethat opens whole world's of emotion. In many ways The Namesake lives up to the expectations that were built around the success of her brilliant short stories. It is an evocative and deeply felt portrayal of family life and the complexity of relationships, the difficult process of trying to assimilate into a new culture and maintain their own cultural connections, identity and belonging. Her character Portrayals are strong and reflect the individual's conflicting emotions. But despite this none of the characters are particularly likeable .Gogol is portrayed as a self centered adolescent intent on distancing himself from his family and their Indian ways and he grows into a 
self centered young adult concerned with making himself an American version of success to re-evaluate his life that you can feel warmth or empathy for him. This question of identity is very crucial for immigrants. Discussing this question of identity, Lahiri explains that:

The question of identity is always a difficult one, but especially so for those who are culturally displaced, as immigrants are, or those who grow up in two worlds simultaneously, as is the case for their children...I think that for immigrants, the challenges of exile, the loneliness, the constant sense of alienation, the knowledge of and longing for the children. On the other hand, the problem for the children of immigrants - those with the strong ties to their country of origin is that they feel neither one thing nor the other.3

There are various factors which determine an immigrant's identity- nationality, occupation, gender etc. The novel describes the struggle between first generation Bengali immigrants to the United States, and their children, particularly their son Gogol. The story beings as Ashoke and Ashima leave Calcutta, India and settle in Cambridge, Massachusetts. Through a series of errors, their son's nick-name, Gogol, becomes his official birth name, an event which will shape many aspects to his life.

At the beginning of the novel we see the first generation immigrant experience from Ashima's point of view. When the novel begins the issue of names and identity is presented. As Ashima's water breaks, she calls out to Ashoke her husband. However, she does not use his name because this would not be proper. According to Ashima,

It's not the type of thing Bengali wives do...a husband's name is something intimate and therefore unspoken, cleverly patched over. 4

While living in America she does not feel any belonging there. Ashima's nature is nostalgic, as a typical immigrant Bengali woman in initial stage she finds it difficult to adjust and adopt herself to the American atmosphere. Her migration disturbs her, but in the course of time she welcomes it as one accepts inevitable. Perhaps, women have the ability to relate to two homes simultaneously. They are able to adopt more quickly and to accept and love two homes without conflict or ambivalence. Ashima is such woman; she has preserved her culture and customs in a foreign land. Lahiri mentions Ashima's thought about migration.Her ability to preserve her culture and keep it alive is tremendous. It is impossible to walk into mist and not getting wet. American lifestyle has its own force to influence, whoever, comes in contact. But at heart and at mind Ashima is pure Indian She takes extra care in Gogol and Sonia's upbringing and teaches them Bengali culture as well as American. She is an ideal mother who takes care of her children without any expectations. After Ashoka's unexpected demise she returns India. Lahiri deliberates her situation with these words: "True to the meaning of her name, she will be without borders, without a home of her own, a resident everywhere and nowhere" (TN, 276). She feels belonging to her mother country i.e India. It is said that home is where the heart is and Ashima's heart is in India, in Kolkata, with her family. After staying in American for more than thirty years, even after securing a driving license and a social security card, which are privileges of in American citizen, Ashima doesn't see home in America. Lahiri, very effectively portrays the predicament of immigrant through her character Ashima.

For thirty three years she missed her life in India. Now she will miss her job at the library, the women with whom she's worked. She will miss throwing parties, she will miss living with her daughter... she will miss the Opportunity to drive...she will miss the country in which she had grown to know and love her husband (TN,279).

Ashima leaves behind her impression of a strong character obstinately rooted in her own culture. After her husband's death she comes to India and feels better in her own home in Calcutta and in her own culture. Like Ashima Ganguli, Askhoke Ganguli has also unspoken affection for his homeland and family. It was his dream that after getting retirement they would return to India, but Ashoke could not see that dream getting fulfilled. Before his retirement he dies Ashoke's character creates a venerable picture of an immigrant who considers his nostalgia as a positive force, to walk ahead and explore the world, to create a place of his own in an alien world. After discussing the first generation immigrant experience which becomes the central theme of the novel. Gogol is the protagonist of the novel, The Namesake. The novel is all about his life, it spans from the day he was in the womb of his mother to the day he invents his self at the age of thirty-two. Gogol is the perfect example of the rootless second generation immigrant. Throughout his life he keeps on struggling with his dual identify with two names : Gogol and Nikhil. He does not like his name because he finds it very shapeless and ludicrous .It neither indicates his belonging with India nor does it suggest anything of America .His alienation with his surrounding is apparent right from the beginning of the novel .He has inherited his sense of loneliness from Ashima .Vogue describes The Namesake as "An explicitly American bildungsroman about the promises and perils of self Invention".5 Another Journal, The Library Journal enthralled it with " This poignant treatment of the immigrant experience and considered it, a rich, stimulating fusion of authentic emotion ,ironic observation , and revealing 
details."6 In India Bengali children are given two names; one that is a pet name, used only by family and close friends and one that is used by the rest of society. At birth ,Gogol is given a pet name as his official name because his official name sent In a letter from his grandmother in India gets lost in the mail .Upon entering kindergarten , Gogol is told by his family that he is to be called Nikhil a good name by teachers and the other children at school. Gogol rejects his proper name and wants to be called Gogol by society as well as his family .This decision made on the first day of kindergarten causes him years of distress as it was also his first attempt to reject a dual identity. The importance of namesake and identity is brought up throughout the story and becomes a concept that is central to the novel .Through his Life Gogol suffers from the uniqueness of his name .In Bengali families"'.......individual names are sacred, inviolable. They are not meant for inheritance and shared"(TN,28). Gogol is traumatized because he takes his Russian name for his identity. Gogol, the protagonist of the novel The Namesake is given a name which he finds misfit on his personality, somehow disgusting, meaningless and shapeless. In the course of changing his name he loses his identity. As Gogol grows up in an American culture he realized that his identity is an imposed one. He thinks that Russian name has nothing India about it, he finds it very suffocating that his name is neither American nor Indian, mere irrelevant, ludicrous, lacking, dignity and gravity. When he turns fourteen, this identity crisis becomes apparent. His situation becomes pathetic because he knows that it was he, who let his pet name turned out to be his good name in the Kindergarten, otherwise his parents have registered him under the name 'Nikhil', but he did not respond to that name because at that time his ear was not habituated to that name. Now, he feels very helpless that,

"He could have been Gogol only 50 percent of time...

He could have had alternative identity, a B-side to the Self (TN, 76)

Anuradha Ghodke writes that Jhump aLahiri herself has two names.

JhumpaLahiri is an excellent writer deals with the major theme of problem of immigrants which she felt in her own life .She is Indian but lived in America, So she faced the problem of immigrants which she tries to show in her work. In the novel The Namesake she used neither two names nor Gogol / Nikhil which is show her own experiences of life .In err life too she has two names that are Nilanjana Sudeshana and JhumpaLahiri.The Namesake is the perfect combination of the life of Indian people living in America.7

Gogol's name becomes a raison d'être for his alienation .His teenage passes by making him more and more introvert .His name makes him feel unconfident, for he thinks that such a weird name does not make an impressive introduction, he could not court girls; no one take him seriously .He finds that his personality is rooted neither in American nor in India:

And so it occurs to him that no one he knows in the world, in Russia or India or American or anywhere, shares his name. Not even the source of his namesake (TN,78)

However, Gogol spends his life living in the United States where children are often ashamed of their differences from others. During adolescence, Gogol desires to blend in and to live unnoticed. Other Americans never view him as an American however even though he is a native born citizen. This presents struggle between two cultures and problem of sense with Bengali culture and values. But Gogol and Sonia grow up relating mostly to their peers and the surrounding culture in the United States. Gogol inherits his sense of alienation and exile from his first generation parents. Like Lahiri he also does not realize to which country he belongs to. He always remains in a confused stage whether he belongs to America or to India. As an attempt to become more familiar with American culture, he keeps on maintaining a distance with his family. He hates his name. Partly, he hates his parents for giving him such obscure name. However, all his dislikes remain unsaid and this troubles him even more. His problem with the name is very genuine for some of his age. Out of this frustrating situation, one day he says: "I don't get it. How could you guys name me after someone so strange? No one takes me seriously" (TN, 100). It is very much later in the novel that he begins truly value their Bengali heritage and that Gogol finds the importance in his name. However, with his developing self-awareness Gogol, in the course of time starts hating his name. He starts with a degree of contempt at his imposed identity from an early age itself. The conflict in plot takes place when Gogol, on his fourteenth birthday, gets a gift of Nikolai Gogol's short stories by his father. His aversion for his name becomes very clear from that day:

He hates having to wear a nametag on his sweater at Model United Nations Day School...He hates that his name is both absurd and obscure, that it has nothing to do with who he is, and that it is neither Indian nor American but of all things Russian. (TN, 76)

He feels that the name hangs on him like a loose overcoat. He wants to get rid of it. His name becomes a factor that distorts his personality into a confused state and his mind into an ambiguous anonymity. He changes his name from 'Gogol', to 'Nikhil'. Sense of alienation does not cease even after changing the name. Perhaps, he is more confused with his dual identity as Gogol for family and Nikhil for outer world. He dreads his visits home and his return to a life where he is known as Gogol. Gogol is not just a name to him; it signifies all his 
discomforts to fit into two different cultures as he grew up. His father named him Gogol due to the circumstances of a train wreck during which he was reading the work of the Russian writer Nikolai Gogol. Being away from home at college makes it easy for Gogol to live as Nikhil in an American culture. He does so happily for many years detaching himself from his roots and his family as much as possible but new name comes with its own dilemma and conflicts. With it he feels at nowhere:

There is only one complication; he does not feel like Nikhil. Not yet. Part of the problem is that the people who now know him as Nikhil have no idea that he used to be Gogol. They know him only in the present, not at all in the past. But after eighteen years of Gogol, two months of Nikhil feel scant, in-consequential. At times he feels as if he's cast himself in a play, acting the part of twins, indistinguishable to the naked eye yet fundamentally different. At times he still feels his old name, painfully and without warning, the way his front tooth had unbearably throbbed in recent weeks after a filling, threatening for an instant to sever from his gums when he drank coffee or iced water and once when he was riding in an elevator. (TN,105).

All his complications and troubles are due to his dual personality, eventually, he tries to erase the former and becomes detached with his family and home .In the course of story he confronts three unfulfilling, unsuccessful affairs. His love life becomes disastrous because he is not confident about the assertion about his identity. His relationship with everybody muddles because he could not get hold of any one fraction of his identity. This, very interestingly, makes an otherwise expatriate theme, a tale of self-invention. He suffers from alienation because first of all he is living in a country to which he does not belong, because the name given to him, again, increase the ambiguity regarding his nationality and thus his identity. The inner conflicts of Gogol reflect in his intimate relationships with women. He hopelessly struggle with his hyphenated identity. Even his marriage does not last long. At each step of his life, he is reminded of his fragile identity as Bengali-American boy. When he celebrates his twenty-seventh birthday with his American girlfriend, Maxine and her parents at a holiday cottage by the lake in New Hampshire, a guest scowled. "All but you're Indian; I'd think the climate wouldn't affect you, given your heritage “( $\mathrm{TN}, 157)$. He feels annoyed with such references. In Gogol's case his self invention ends in accepting his identity as it is-containing, two names, two cultures-half Indian, half American. He realized that he cannot escape from his name, and thus from his hyphenated identity, he realizes the origin of his true name, the name as lifeline that links him to the identity he has refused to accept and which has nothing Russian about it. He recognizes that being an immigrant, his fractured self is his only identity. He thinks:

The name he had so detested, here hidden and preserved - that was the first thing his father had given him... without people in the world to call him Gogol, no matter how long he himself lives, Gogol Ganguli will, once and for all, vanish from the lips of loved ones, and so, cease to exit. (TN, 289).

He accepts that he can neither change his destiny nor his name. And the clash of that dual identity has proven a chain of miserable incidents. The pervasive loneliness tells upon the relations and happiness of various characters and adversely affects their identity. Lahiri, through Ashima and Ashoke, portrays the first generations of immigrants and elaborately meditates on their state of solitude. Loneliness is the crowing effect of the novel. It is diffused in the entire atmosphere. Ashima while arriving at Cambridge, could not get herself psychologically settled down in that place, especially when she is pregnant, Lahiri describes her state:

But nothing feels normal to Ashima. For the Past eighteen months, ever since she's arrived in the Cambridge, nothing has felt normal at all, it's not so much the pain, which she knows somenow, she will survive. It's the consequence motherhood in a foreign land...that it was happening so far from home, unmonitored and unobserved by those she loved, had made it more miraculous still. But she is related to no one, where she knows so little, where life seems so tentative and spare. (TN, 5-6)

Nostalgia for one's own homeland often problematizes the identity of an immigrant. The tug-of-war between the distant past and isolated present is made further cruel by the absence of family/society. The vacuum disorients the immigrants to the extent that they hanker after relocating themselves in this adopted culture. For an Indian to raise children, to lead happy and secure life, a society is must. Society, community and culture are a shelter as well as a safeguard behind which an individual grows and finds his roots. And when that shield is removed, such a person becomes unprotected, uprooted, dislocated. For immigrants like Ashima, maintaining ties to India and preserving Indian traditions in America means a lot. Once Ashima asks Askoke, after her delivery, that she feels so lonely,

I'm saying hurry up and finish your degree. I'm saying I don't want to raise Gogol alone in this country. It's not right; I want to go back (TN, 33).

Ashoke's loneliness and sense of exile becomes apparent from his fondness for Nikolai Gogol. Once he explained Gogol, his son, "I feel a special kinship with Gogol more than any writer .......He spent most of his 
adult life outside his homeland .Like me" (TN, 77). Throughout the novel, he keeps a pregnant silence .This one sentence describe his loneliness and nostalgic nature very strikingly.

Time also plays an important factor as Lahiri has effectively portrayed the chasm of exile between first and second generations of immigrants. The second generation, whose parents still cling to old traditional beliefs, feels trapped by their differences, not only at school but at home. However, with the resilience of youth, most of them find a balance, and they may start appreciating aspects of their heritage culture. But there is vast difference between their attitudes to 'home' and their parents. Many immigrant children feel the stings of racism in their school environment and carry the scars of trauma all their lives. When Gogol and Sonia return from Calcutta, they both observe that nobody notices their absence. "They call up their American friends, who are happy enough to see them but ask them nothing about where they've been."(TN, 88)

The Indian part of an immigrant child thus, always remains 'unacknowledged and negated' by the foreign cosmopolitan environment. So, from the very childhood they carry this disrootedness and sense of exile. In some ways Lahiri herself struggle to understand Indian culture. In an interview with India- west, Lahiri admits; "I'm lucky that I'm between two words.... I don't really know what a distinct South Asian identity means. I don't think about that when I write, I just try to being a person to life," And that is exactly what she does through her characters. Addressing the themes of means immigration, Collision of cultures and the importance of name in The Namesake, Lahiri demonstrates how much of a struggle immigration can be.The experiences of migration vary from person to person, depending upon the level of education, age, background and the point of entry .Acceptance or rejection by a host culture depends upon the value of the person, his use to the new society , his educational level and his social milieu. The same theme of migration with a different background of Ganrglia family creates an altogether different outlook. JhumpaLahiri successfully brings the reader closer to the migrant life ,in the novel from its microscopic presentation. Gogol's indifferent attitude towards his family, cynical views regarding his name and the lack of involvement with his surroundings mark him as a complete outsider. He makes sporadic efforts to unite himself into any relation, but his attempts are doomed. Until the climate scene at the end, shorn off an emotional connection, Gogol is looking for a meaning in life .In the end he recognizes his roots, start his spiritual journey to explore life. Gogol inhabits in a world in which there is no axis. It is a collapsible and deceptive, where the state of exile is a cultural as well as emotional denial .This world is pitted against the world of his parents' who are permanently outsiders despite the driving his parents' who are permanently outsiders despite the driving license and security card, but somehow protected with I the immigrants' cultural safety net. Various events play a crucial role in the development of Gogol's personality. His life up till thirty is a chain of miserable memories, relationship or career, more or less he is nowhere. Life has taught its most matter of fact rules in very painful manner. For Gogol, each happening becomes a lesson to invent his self, understand life in its gray shade. At the end, he eventually gets rid of his dilemmas regarding life. He reaches at a stage when he realizes his experience in totally, as integrated where each ad every happy and unhappy moment of life contains a deeper meaning to enhance his soul. The entire novel turns out to be spiritual journey of a man in search of his soul, his identity, in search of deeper meanings of life. The pervading mood of the novel is tragic. Gogol hardly encounters moments where his self and surrounding is not at conflict. But in the end, he learns to accept his self as it is; every incident is an inextricable part of his life; every relationship, as a lesson to understand the ongoing emotional expedition. He reaches at a juncture where he introspects into his nature, in an attempt to improve his existence. With his modified perceptions, he starts a new journey to explore life all alone.

Gogol, by the time the novel reaches its conclusion, is not overtly delighted but as his namesake, finally returns to the only place he has to go back, he seeks out the original as homage and redemption. Lahiri mentions in the end of the novel,

In another ten years, Gogol Ganguli will be that age. He wonders if he will be married again one day, if he will ever have a child to name. A month from now he will begin a new job at a smaller architectural practice, producing his own designs. There is a possibility, eventually, of becoming an associate, of the firm incorporating his name. And in that case Nikhil will live on, publicity celebrated, unlike Gogol, purposely hidden, legally diminished, now all but lost ( TN, 289-90).

Last page of the novel describes Gogol's self contentment. His soul searching attitude takes on a new dimension a new life. He reinvents his name, his identity, his namesake. There is deep influence of BhagvadGita also. Gogol's whole career seems to illustrate.

"One has to understand what action is, and likewise one has to understand what is wrong action and about inaction. Hard to understand is the way of work (Gita-4.17').8

Gogol feels identity crisis at the beginning of the novel and reaches at the conclusion that there is no escape from action and identity and action is better than inaction. He tries to find his roots, his identity and finally learns the lesson of action preached by existential philosophy. He realizes that the only way for an immigrant to 
get rid of identity clashes is to accept that dual, fragile and hyphenated identity. Perhaps each and every individual is alone on this earth. One has to establish his root, carve his own path, and explore the world all alone without being attached to any emotionally. When Gogol returns Calcutta with his mother Ashima as a widow then he realizes the origin of his true name. His self-invention comes to an end with an acceptance. He finally learns the lesson that the answer is not fully abandon or attempt to diminish either culture, but to mesh the two together Gogol is not fully in tune with his identity until he realize that is embellished by both cultures. He does not have to be one or the other; he does not have to choose. He is made up of both, and instead of weakening, his pride is strengthened by this. Though the novel wraps up with more down falls occurring in Gogol's life he is able to stand on his feet. He is proud of who he is and where he comes from. Most important he is proud of his name and all that it means. He accepts the reality of his name recognizes his roots and feels belonging to his mother, sister and other people. He starts his new life in Calcutta but with a newly found acceptance. He feels the fact of life that detachment is not the resolution of any problem. His journey starts from detachment/ non involvement and ends with getting involved and belonging to everyone.

I would like to conclude by saying that after going through Lahiri's novel The Namesake, one can conjecture the only solution, that is to accept the fact that all expatriation involves anxiety and belonging to two ethic groups which force a kind of struggle with something, other people do not have to struggle with. That growth is painful, but that is an inextricable part of the immigrant experience. Expatriation is the recognition of hyphenated fluid identity, an acknowledgement of alternate realities.

\section{References:}

[1]. Michiko Kakutani: in a review published in 2nd September, 2003. Quoted from, "The sense of exile, Alienation and Assimilation in JhumpaLahiri's Fiction, Post Colonial Women Writers New Perspective, ed. SunitaSinha ( New Delhi, Atlantic publishers and distributors, 2008), pp.192.

[2]. Interview with Vibhuti Patel in Newsweek quoted from Suchita Joshi, "The Namesake: Account of a name looking for its Bearer", Indian Women Novelists in English, ed P.D. Bheda (New Delhi: Prestige Books, 1993) pp-91.

[3]. Interview released by A Houghton Miffin Company appeared on internet, quoted from, ibid, pp-91.

[4]. JhumpaLahiri, The Namesake (New Delhi: Harper Collins publishers Indai, 2003) pp-2. All subsequent textual quotations are from the same edition, identified the novel's short form TN and their respective page numbers within parenthesis at the end of each quote.

[5]. Suchita Joshi, "The Namesake: Account of a name looking for its Bearer", Indian Women Novelists in English, ed P.D. Bheda (New Delhi: Prestige Books, 1993), pp-116.

[6]. The Namesake: Summary and book reviews of The Namesake by JhumpaLahiri, plus links to an excerpt from The Namesake and a biography of JhumpaLahiri< http/www.book-browse, com/reviews/index.cfm?book-number- 127723 April 2010 , pp-2.

[7]. AnuradhaGhodke, "Indian- American life theme immigrateJanuary6,2010<http://hindusimabout,com/cs/books/fr/namesakehtm, April, 2010.

[8]. O.P Mathur" Survival and Affirmation in Arun Joshi/s Novels" ed. The Modern Indian English Fiction. ( Noida:- Abhinav Publication, 1993), pp-128.

\section{BIBLIOGRAPHY:}

\section{PRIMARY SOURCES}

\section{JhumpaLahiri}

\section{Fiction}

Lahiri, Jhumpa. The Namesake. New Delhi: Harper Collins Publishers India, 2003

\section{SECONDARY SOURCES}

Abrams, M.H. A Glossary of Literary Terms. $7^{\text {th }}$ Bangalore: Prism, 2003.

Bheda, P.D. Indian Women Novelties in English. New Delhi: Sarup and Sons, 2005

Chandra, N.D.R Contemporary Indian Writing in English: Critical perceptive. Vol-II. New Delhi :Sarup and sons, 2005

Pathak, V. Dabir, Urmila and Mishra Shubha. Contemporary Fiction An Anthology of Female Writes. New Delhi :Sarup and sons, Ist ed. 2008.

Sinha, Sunita .Post -Colonial Women writers New Perspective. New Delhi: Atlantic Publishers, 2008.

\section{ARTICLES}

Joshi Suchita. “ The Namesake : Account of a name ,Looking for its Bearer ”,ed. P.D. Bheda .Indian women Novelists in English. New Delhi: Sarup and sons, 2005.

Mathur, O.P. "Arun Joshi and the Gita”. ed. R.S. Pathak. Indian Fiction in English : problems and promises . New Delhi: Northern Book Centre, 1990.

\section{ELECTRONIC SOURCES}

"Absurdism" from Wikipedia ,the free encyclopedia. Online last modified 2 Dec.2009.

http://en.wikipedia.org/wiki/Absurdism Retrieved on 5 Dec.2009.

Das Subhamony." A Hindu Family's American Journey ''.Online.

http://hinduism.about.com/cs/book/fr/namesake.htm. Retrieved on 22 April, 2010. 
Gullettle, Alan. "Fiction of the Absurd ." online -last updated 9 Oct. 2004 http://alangullette. Com/lit/absurd/ . Retrieved on 5 December ,2009.

“Interpreter of Maladies" From Wikipedia, the free encyclopedia, online, Last modified 26 Sep.2009.http://en.wikipedia.org/wiki/Interpreter of Maladies. Retrieved on 5 Dec,2009.

KaKutani, Michiko.' Books of the Times; From Calcutta to Suburbia: A family's Perplexing Journey." Online, last modified 2 Sep, 2003. http//www.nytimes.com/2003/9/02 books -of-the-times-fr......23 April,2010.

Lahiri, Jhumpa.' The Namesake' , online .http://www/library thing.com/work/3015. Retrieved on 23 April,2010. .."Book Review the Namesake", online. http://www.allreaders.com/Top ics/info-2 5423.asp.Retriveved on 23 April,2010.

..from Book Browse: com. online, http://www.book browse,

com/reviews/index, cfm? book-number 1277.23 April,2010.

Nawale, Dr. Arvind M. "Indian English Fiction: An Appraisal”, online. http://www.literature-studyonline.com/Essays/Indian-English.........Retrieved on 20 sep,2009.

"Unaccustomed Earth" from Wikipedia, the free encyclopedia online. Last modified April ,2008.http://en.wikipedia.org/wiki/unaccustomed Earth. Retrieved on 28 Sep, 2009. 